Review

\title{
Reviewing the Analytical Methodologies to Determine the Occurrence of Citrinin and Its Major Metabolite, Dihydrocitrinone, in Human Biological Fluids
}

\author{
Liliana Silva ${ }^{1, *}(\mathbb{0})$, André Pereira ${ }^{1}$, Sofia Duarte ${ }^{1,2}$, Angelina Pena $^{1}$ and Celeste Lino ${ }^{1}$ \\ 1 LAQV, REQUIMTE, Laboratory of Bromatology and Pharmacognosy, Faculty of Pharmacy, \\ University of Coimbra, Polo III, Azinhaga de St ${ }^{\mathrm{a}}$ Comba, 3000-548 Coimbra, Portugal; \\ amptpereira@gmail.com (A.P.); s.cancela.duarte@gmail.com (S.D.); apena@ci.uc.pt (A.P.); \\ cmlino@ci.uc.pt (C.L.) \\ 2 Vasco da Gama Research Centre-Department of Veterinary Sceinces, Escola Universitária Vasco da Gama, \\ Av. José R. Sousa Fernandes, Campus Universitário-Bloco B, 3020-210 Coimbra, Portugal \\ * Correspondence: ljgsilva@ff.uc.pt; Tel.: +351-239-488-400; Fax: +351-239-488-503
}

Academic Editor: Terenzio Bertuzzi

Received: 21 May 2020; Accepted: 19 June 2020; Published: 24 June 2020

check for updates

\begin{abstract}
Until now, the available data regarding citrinin (CIT) levels in food and the consumption of contaminated foods are insufficient to allow a reliable estimate of intake. Therefore, biomonitoring configuring analysis of parent compound and/or metabolites in biological fluids, such as urine or blood, is being increasingly applied in the assessment of human exposure to CIT and its metabolite, dihydrocitrinone (DH-CIT). Most studies report urinary levels lower for the parent compound when compared with DH-CIT. A high variability either in the mean levels or in the inter-individual ratios of CIT/DH-CIT between the reported studies has been found. Levels of DH-CIT in urine were reported as being comprised between three to seventeen times higher than the parent mycotoxin. In order to comply with this objective, sensitive analytical methodologies for determining biomarkers of exposure are required. Recent development of powerful analytical techniques, namely liquid chromatography coupled to mass spectrometry (LC-MS/MS) and ultra-high-performance liquid chromatography (UHPLC-MS/MS) have facilitated biomonitoring studies, mainly in urine samples. In the present work, evidence on human exposure to CIT through its occurrence and its metabolite, in biological fluids, urine and blood/plasma, in different countries, is reviewed. The analytical methodologies usually employed to evaluate trace quantities of these two molecules, are also presented. In this sense, relevant data on sampling (size and pre-treatment), extraction, cleanup and detection and quantification techniques and respective chromatographic conditions, as well as the analytical performance, are evidenced.
\end{abstract}

Keywords: citrinin; dihydrocitrinone; biomonitoring; urine; blood; plasma; analytical methodologies

\section{Introduction}

Mycotoxins, secondary toxic metabolites, are produced by some fungal species, such as Aspergillus, Penicillium, Fusarium and Alternaria, in both crops and processed food commodities under favorable conditions namely of moisture, temperature and water activity [1,2].

Among the more than 400 mycotoxins already identified and reported, those that attracted notable attention for the toxic effects and high prevalence in the agro-food commodities are aflatoxins (AFs), ochratoxin A (OTA), trichothecenes (deoxynivalenol (DON) and nivalenol (NIV)), fumonisins (FBs), zearalenone (ZEN), patulin (PAT) [1-3] and citrinin (CIT) [2,3]. 
Citrinin (CIT) was first discovered in 1931 due to its antibiotic properties but it was never used because of its mammalian toxicity [4]. This polyketide mycotoxin is produced by fungi belonging to the genera Penicillium, Aspergillus and Monascus [5]. It was first isolated from Penicillium citrinum before World War II. Afterward, it was identified in several Penicillium (e.g., P. citrinum, P. expansum, P. radicicola, P. verrucosum) and Aspergillus (e.g., Aspergillus terreus and Aspergillus niveus) species, as well as certain strains of Penicillium camemberti and Aspergillus oryzae. CIT has also recently been isolated from Monascus ruber and Monascus purpureus [6,7]. Dihydrocitrinone (DH-CIT) was isolated in 1962 from a mutant strain of Aspergillus terreus that did not produce CIT, being later demonstrated as a regular metabolite in both Penicillium citrinum and Aspergillus carneus [8].

Cereals, such as rice, wheat, oats, rye, corn and barley, were described as the foods containing higher CIT levels [6]. However, it has also been found in black olives [9,10], fermented meat products [11], cheese [12] and apples [13].

Exposure to CIT is of toxicological concern and its toxicity has been thoroughly investigated. CIT disturbs the kidney function in several species, namely in the renal tubules [14]. CIT induced micronuclei in human-derived liver cells (HepG2) at levels equal to or greater than $10 \mu \mathrm{M}$ and decreased in a dose-dependent way the percentage of binucleated cells [15].

In Japan, CIT has been related with yellow rice disease. It was further implicated as causative contributor in swine nephropathy. Although recognized as a nephrotoxin in all tested animal species, its acute toxicity is variable across the different species $[6,16]$. CIT is an acknowledged nephrotoxin that affects monogastric species like pigs and dogs [17]. However, on humans the effects of this mycotoxin are not yet fully known. Synergistically with ochratoxin A (OTA), CIT can decrease the synthesis of RNA in the kidneys of murine models [6].

Studies regarding CIT toxicity recognized the kidney as the main target organ following repeated dose exposure in animals. Thus, CIT resembles OTA, although clearly featuring lower nephrotoxic potency [14]. Co-occurrence of these two nephrotoxins in different commodities of the animal and human food chain raised concerns about the potential risks to human and animal health [18]. CIT and OTA are associated with the etiology of porcine nephropathy and of Balkan endemic nephropathy (BEN) in humans $[19,20]$. However, due to limited evidence for carcinogenicity in experimental animals CIT was classified by IARC in group $3[7,14]$.

Following the biotransformation of CIT, the main metabolite formed appearing in the human urine is dihydrocitrinone (DH-CIT) [21,22]. The toxicity of DH-CIT was investigated, and the studies revealed that its cytotoxic potency was clearly lower compared with CIT as well as its genotoxic potential [23]. The metabolism of CIT in DH-CIT can thus be considered as a detoxification reaction.

Chemically, CIT is a quinone featuring two intramolecular hydrogen bonds [24]. It is identified as (3R,4S)-8-Hydroxy-3,4,5-trimethyl-6-oxo-4,6-dihydro-3H-isochromene-7-carboxylic acid, the chemical formula $\mathrm{C}_{13} \mathrm{H}_{14} \mathrm{O}_{5}$ (Figure 1) and CAS Number 518-75-2. The molecular weight of CIT is $250.25 \mathrm{~g} / \mathrm{mol}[5,16]$. DH-CIT, also known as HO-CIT, is (3R,4S)-6,8-Dihydroxy-3,4,5-trimethyl-1-oxo-3,4-dihydro- $1 H$-isochromene-7-carboxilic acid and the chemical formula $\mathrm{C}_{13} \mathrm{H}_{14} \mathrm{O}_{6}$ (Figure 1) [18]. Citrinin is described has solid lemon-yellow needles, with color changing according to the $\mathrm{pH}$ in solution. It is lemon-yellow at $\mathrm{pH} 4.6$ whereas at $\mathrm{pH} 9.9$ it is cherry red. The melting point of CIT is $178.5^{\circ} \mathrm{C}$. In cold water it is practically insoluble whereas in hot water it is moderately soluble. It is soluble in the majority of polar organic solvents, including methanol, ethanol and acetonitrile, as well as in aqueous sodium hydroxide, sodium carbonate and sodium acetate [24,25].

Biomarkers of exposure either in urine and/or plasma are considered a useful tool in the evaluation of the internal mycotoxin exposure in humans [15]. Biomarkers are particularly useful whenever food analysis data is limited or inadequate, as in the case of CIT. Thus biomonitoring, as the analysis of human biological fluids for suitable biomarkers of exposure reflecting the dietary intake, permit a valuable understanding on human exposure to this mycotoxin $[15,18]$. 


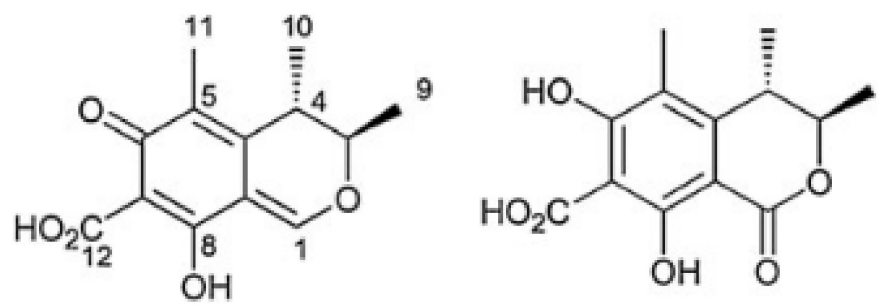

Figure 1. Citrinin (CIT, on the left) and dihydrocitrinone (DH-CIT, on the right) $[22,26]$.

This paper presents a review of different studies on human exposure to CIT worldwide, through the occurrence of the mycotoxin and of its metabolite, DH-CIT, in human urine and plasma. In this sense, relevant data on sampling, such as size and pre-treatment, extraction and cleanup strategies are reported. The use of adequate and sensitive analytical methodologies for detection and quantification and respective chromatographic conditions, as well as the analytical performance achieved, for both molecules, is evidenced. The vast majority of methods applied so far in the evaluation of CIT biomarkers rely on LC-MS/MS analysis. However, some authors also applied liquid chromatography-fluorescence detector (LC-FD), as an alternative given that, due to its planar structure, CIT has natural fluorescence [24]. Many different sample preparation strategies aiming the selective enrichment of the analytes have been described in literature are widely employed nowadays, namely liquid-liquid extraction (LLE) and solid phase extraction (SPE). Direct 'dilute-and-shoot' (DaS) approaches have been tried but its efficiency can be compromised when low concentrations of the analyte are present. Furthermore, the co-eluted matrix components can affect ionization of the target analytes.

A comprehensive review has been conducted covering the last decade of published references in this topic. Several database platforms such as PubMed, Science Direct and Google Scholar were used for the search. The keywords used individually or in combination in the search list, were citrinin, occurrence, biological fluids and analytical methodologies. Due to the lack of data on the presence of CIT in breast milk [27], this biological fluid was not included in this review.

\section{Occurrence in Biological Fluids}

A suitable risk assessment of CIT is hampered by the very incomplete knowledge on human dietary exposure to this mycotoxin [14]. Whenever food contamination data are limited or unavailable, biomonitoring constitutes a valuable and effective strategy in the assessment of human CIT exposure. However, it relies on sensitive analytical methods and information on toxicokinetics [28].

Internal exposure assessed through biomonitoring analysis of target chemicals, metabolites or reaction products in urine or plasma can relate exposures to health outcomes. Regular methods are suitable for biologically persistent chemicals. However, the effective evaluation of short-lived chemicals depends on a continuous exposure or knowledge of the timing of exposures in the individual. In particular, urinary excretion mainly represents recent mycotoxin intake, reflecting short-term exposure with more day-to-day variation [29], whereas measurements in plasma/serum are more likely to represent long-term exposure [30].

\subsection{Urine}

Urine is oftentimes the matrix of choice for the ease of collection. Nevertheless, the different fluid intakes result in different urine excretion. Such limitation can be mitigated through normalization for the creatinine concentration in the samples. For exposure assessment, collection of 24-h urine is recommended. Studies on the stability of many different target analytes showed that these were stable up to $12 \mathrm{~h}$ at $25^{\circ} \mathrm{C}$ after collection [31]. However, it is recommended a conservation at $2-4{ }^{\circ} \mathrm{C}$ to prevent fermentation that could affect the sample components [30]. 
As mentioned before, data on contamination of food with CIT is scarce which preclude the evaluation of dietary exposure. Despite availability of data resulting from urinary biomonitoring performed in different countries, the lack of information on the toxicokinetics of CIT hinders the estimation of daily intake [26].

After rapid absorption, CIT is distributed namely to the liver and kidney. According to a recent study on human toxicokinetics, $40 \%$ of CIT underwent urinary excretion and thus absorption was equal to or higher than $40 \%$ [32]. CIT toxicokinetics in humans following oral intake were further reported [27]. After ingestion, CIT is converted into the main metabolite DH-CIT, being both excreted in the urine. In $24 \mathrm{~h}$ the cumulative urinary excretion ranged between $32.9 \%$ and $70.8 \%$ (median $40.2 \%$ ) of the sum of CIT and DH-CIT ('total CIT'). In urine, the median half-life of CIT and DH-CIT was reported as $6.7 \mathrm{~h}$ and $8.9 \mathrm{~h}$, respectively. CIT was excreted in urine after 20 to $22.5 \mathrm{~h}$ of administration. The greatest excretion pattern of CIT and DH-CIT after administration in humans was set at 22.5 h [26]. Nevertheless, data concerning the CIT metabolism and excretion rate resulted from a study enrolling two single participants, with highly variable results [26]. The two volunteers, both health females, identified as individual A and B, ingested CIT twice (spaced out some weeks) at doses lower than the TDI. The half-lives of the biomarkers in urine were estimated as $5.5 \mathrm{~h}$ and $6.3 \mathrm{~h}$ (in the case of CIT; mean: $6.7 \mathrm{~h}$ ) and $7.5 \mathrm{~h}$ and $9.2 \mathrm{~h}$ (in the case of DH-CIT; mean: $8.9 \mathrm{~h}$ ), for individual A and B, respectively [26].

Conversely to the limited literature on the toxicokinetics and metabolism of CIT in humans, in rats DH-CIT was isolated and effectively identified as the predominant urinary metabolite of CIT already in 1983 [31]. In the urine of rats CIT was not detected [32].

Table 1 shows CIT and DH-CIT data, known so far, in human biological fluids in different countries. Overall, most studies report urinary levels lower for the parent compound when compared with the major metabolite (DH-CIT). The high variability in either the mean levels or the inter-individual ratios of CIT/DH-CIT is also noticeable [33]. Levels of DH-CIT in urine were reported as being three [5], five [18], ten, thirteen and seventeen times [34] greater than the parent mycotoxin. Although the enzymes that catalyze such detoxification reaction are not yet known, it is recognized that this conversion can be variable individuals. Therefore, it is recommended that biomonitoring studies should include analysis of both CIT and DH-CIT and interpret results in light of individual and combined (sum of both analytes) levels [24,30].

Table 1. CIT and DH-CIT occurrence in human biological fluids in different countries.

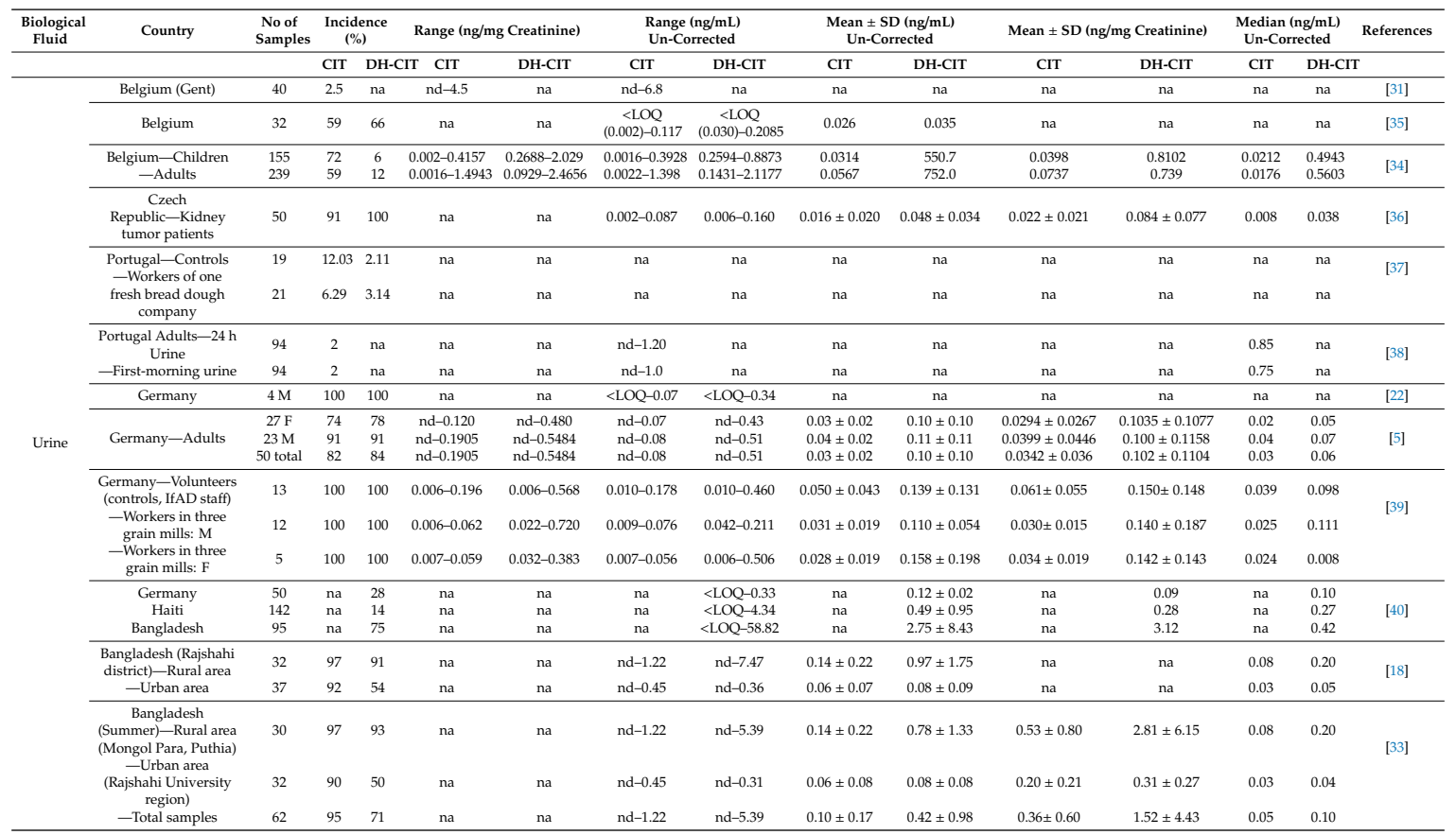


Table 1. Cont.

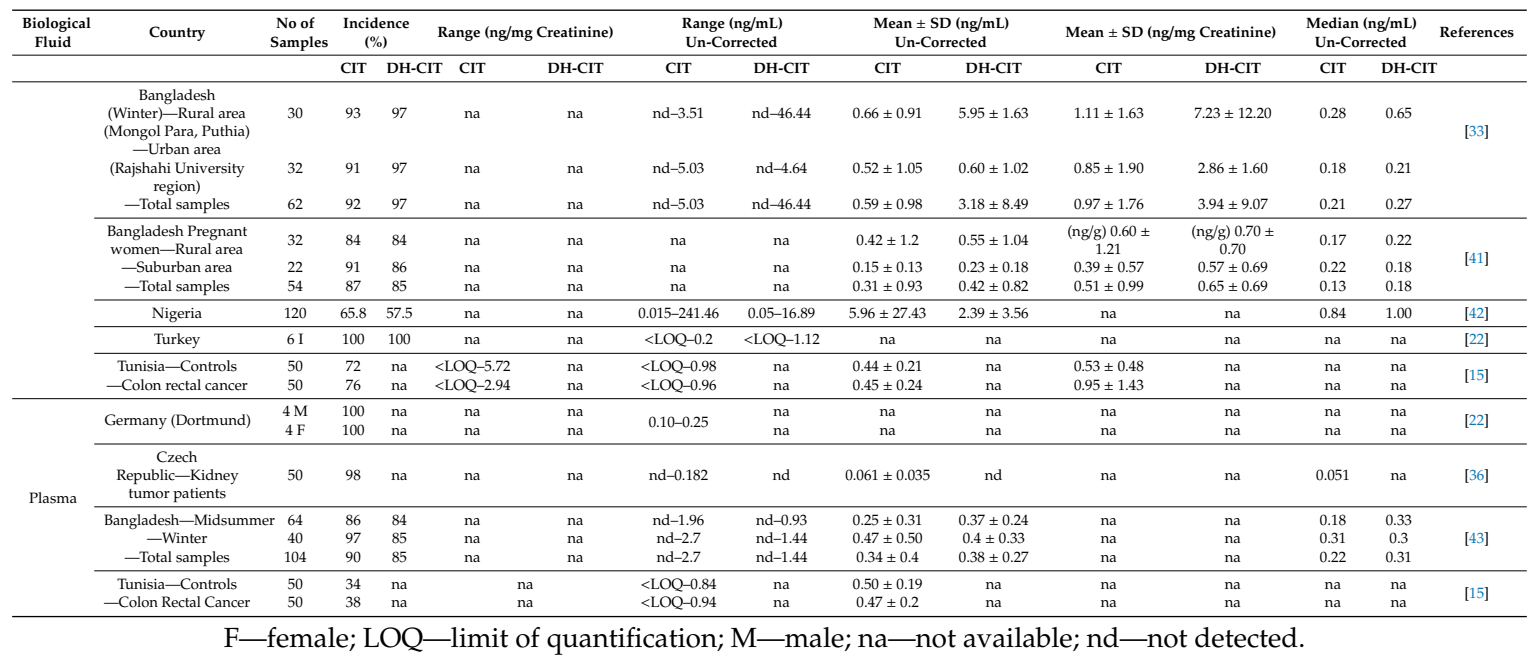

In human urine, the un-metabolized mycotoxin was detected at low levels (ranging from 2 to $5 \mathrm{ng} / \mathrm{mL}$ ), demonstrating the possibility of urinary excretion, although at low levels. Such feature hinders the detection of CIT in food and biological samples in routine analysis.

In Belgium, CIT was detected in a single sample among the 40 samples analyzed, with a contamination level of $6.8 \mathrm{ng} / \mathrm{mL}$ (value un-corrected) [31]. Another study evaluated the urine of a small cohort comprising 4 adults (German) and 6 infants (Turkish) [22]. In the ten urines analyzed, CIT was detected (above the limit of quantification (LOQ) in 8 samples whereas DH-CIT was detected in the ten samples but with values above the LOQ in half of the samples. According to such results, urinary excretion occurred mainly in the form of the un-metabolized mycotoxin and to a lesser extent in the form of DH-CIT.

A similar study performed in fifty German health adults, of which 27 women and 23 men reported a widespread and variable exposure to CIT [5]. The un-metabolized mycotoxin was detected in $82 \%$ of the samples, varying between 0.02 (limit of detection (LOD) and $0.08 \mathrm{ng} / \mathrm{mL}$, with a mean level of $0.03 \mathrm{ng} / \mathrm{mL}$. DH-CIT was found in $84 \%$ of the samples, ranging between 0.05 (LOD) and $0.51 \mathrm{ng} / \mathrm{mL}$, with a mean level of $0.10 \mathrm{ng} / \mathrm{mL}$. The adjustment to creatinine content resulted in three times higher level of the metabolite DH-CIT $(60.9 \mathrm{ng} / \mathrm{g})$ compared to the parent compound $(20.2 \mathrm{ng} / \mathrm{g})$, thus supporting its usefulness as a CIT exposure biomarker [5]. Further studies demonstrated the widespread occurrence of DH-CIT in urine, reflecting an extensive conversion of CIT to DH-CIT and thus supporting an effective human metabolism of CIT [23]. Also, in Germany, a study evaluated exposure to CIT of female and male workers in three grain mills in North Rhine Westphalia, through collection of spot urine. A third cohort corresponded to male controls [39]. Although both mycotoxin and metabolite were detected in all samples analyzed, DH-CIT showed average levels three times higher ( 0.045 vs. $0.14 \mu \mathrm{g} / \mathrm{g}$ creatinine). Furthermore, the median levels of the metabolite $(110 \mathrm{ng} / \mathrm{g}$ creatinine) were equally superior to those of CIT ( $40 \mathrm{ng} / \mathrm{g}$ creatinine), in the three groups enrolled. This study thus reinforced the value of this less toxic metabolite in the human exposure assessment of CIT [39].

In Belgium, first morning urine samples of 32 volunteers were analyzed for CIT and DH-CIT. It was observed a widespread contamination, with $90 \%$ of the urine samples contaminated though at low levels (pg/mL). CIT was detected in $59 \%$ of the samples at levels up to $117 \mathrm{pg} / \mathrm{mL}$ whereas DH-CIT, considered a detoxification product and a major hepatic metabolite of CIT, was detected in $66 \%$ of the samples at levels up to $208.5 \mathrm{pg} / \mathrm{mL}$ [23,44]. A further study in the same country, showed that $72 \%$ of adult $(n=239)$ and $59 \%$ of children $(n=155)$ analyzed urine samples contained CIT at low mean levels ( $<73.3 \mathrm{pg} / \mathrm{mg}$ creatinine). The DH-CIT mean levels were higher than the parent compound in both adults (752.0 vs. $56.7 \mathrm{pg} / \mathrm{mL} ; 13$ times higher) and children (550.7 and $31.4 \mathrm{pg} / \mathrm{mL} ; 17$ times higher). 
Conversely, the contamination frequency was lower when compared with the parent compound, in both adults (12\% vs. $59 \%)$ and children (6\% vs. $72 \%)$ [34].

In Portugal, the National Food, Nutrition and Physical Activity Survey of the Portuguese General Population (2015-2016), conducted through analysis of urine paired samples (24 h urine and first-morning urine) of 94 individuals revealed a low exposure to CIT. Indeed, the mycotoxin was only detected in $2 \%$ of both samples, from two participant women, with one surpassing the established TDI $(\mathrm{HQ}=1.04)$ [38]. In a further study in Portugal, the mycotoxin and the major metabolite were evaluated in the urine of controls $(n=19)$ and workers $(n=21)$ of a fresh bread dough company [37]. CIT was found in one control sample above the LOQ (5\%) and in 10 samples $(53 \%)<$ LOQ. DH-CIT was found in 2 samples between the LOD and LOQ and $17<$ LOD. Among the employees, 3 urine samples contained DH-CIT levels between LOD and LOQ and $18<$ LOD. Occupational exposure was also evaluated in 25 employees of swine farms, through analysis of urine samples. Eight per cent and $12 \%$ were contaminated with CIT and DH-CIT, respectively. The control group $(n=19)$ showed a lower number of quantifiable results $(<\mathrm{LOQ})$ [45].

Recently, CIT and DH-CIT exposure was evaluated in fifty Czech patients diagnosed with malignant renal tumors [36]. CIT and DH-CIT were detected in 91\% (ranging from nd to $87 \mathrm{ng} / \mathrm{L}$ ) and $100 \%$ (ranging from 6 to $160 \mathrm{ng} / \mathrm{L}$ of the urine samples, respectively. Urine samples $(n=1096)$ from Swedish adolescents showed that $1.5 \%$ of the population was contaminated with DH-CIT [46].

A study performed in Bangladesh showed a widespread contamination along with five times higher levels of DH-CIT in urine when compared with CIT. Despite the individual variability observed in the ratios of urinary CIT/DH-CIT [1.3-6.6], the metabolite proved to be a valuable biomarker of exposure to CIT. Among the 69 urine samples evaluated, CIT was detected in $94 \%$ (up to $1.22 \mu \mathrm{g} / \mathrm{L}$ ) and the metabolite DH-CIT in $71 \%$ (up to $7.47 \mu \mathrm{g} / \mathrm{L}$ ). The results also showed that contamination levels were higher among the rural population in comparison with the urban population. Although uncertain, such difference probably related with diverse eating habits and/or occupational exposure [18].

Also, in Bangladesh, exposure to CIT among pregnant women living in both rural and suburban are of the Savar region (District of Dhaka) was evaluated. It was observed a widespread contamination in the 54 spot urine samples analyzed, with $87 \%$ contaminated with CIT at levels varying between 0.02 and $6.93 \mathrm{ng} / \mathrm{mL}$. In all the analyzed samples, the levels of the DH-CIT metabolite were 1.5 times higher when compared with CIT According to the residency, in the rural area 84 and $84 \%$ and in the suburban area, 91 and $86 \%$ of the samples were contaminated with CIT and DH-CIT, respectively (Table 1). Contamination levels of both compounds were two times higher among the rural population when compared with the suburban population, thus supporting the results of the previously mentioned study [41]. As a result, the estimated daily intake for the rural population was higher than for the suburban population. For CIT, the preliminary TDI is established at $0.2 \mu \mathrm{g} / \mathrm{kg}$ body weight per day based on no concern for nephrotoxicity in humans [14]. The authors reported that $9 \%(n=3)$ of the pregnant women from the rural area $(n=32)$ surpassed the proposed TDI. The highest EDI calculated among the pregnant women living in the rural area was $1.09 \mu \mathrm{g} / \mathrm{kg} \mathrm{bw} /$ day, which is thus 5 times higher that the proposed TDI. No significant association was observed between exposure biomarkers in urine and the food commodities consumed. Nonetheless, total CIT levels were greatly higher in the pregnant women consuming more rice daily [41].

A biomonitoring survey for DH-CIT in human urine samples from Bangladesh, Germany and Haiti was reported. The average concentration $(2.75 \mathrm{ng} / \mathrm{mL})$ among the Bangladeshi participants was higher among the $76 \%$ contaminated urine samples, when compared with the German and Haitian participants ( 0.12 and $0.49 \mathrm{ng} / \mathrm{mL}$ ) [40]. In a previous study conducted in the German city of Munster, the authors found a single sample containing DH-CIT from the 101 urine samples collected from healthy volunteers [47].

In Bangladesh, a biomonitoring follow-up study was carried out to examine potential regional and seasonal determinants of CIT exposure [33]. Detection of the parent compound revealed noticeable variations. The contamination levels were higher for DH-CIT than for CIT, in both summer $(0.42 \pm 0.98 \mathrm{vs}$. 
$0.10 \pm 0.17 \mathrm{ng} / \mathrm{mL})$ and winter $(0.59 \pm 0.98 \mathrm{vs} .3 .18 \pm 8.49 \mathrm{ng} / \mathrm{mL})$ collected samples. The rural population presented higher total CIT biomarker levels when compared with the urban population, whether in summer or winter season. However, the average concentration of CIT and DH-CIT was significantly $(p<0.05$ and $p<0.01)$ higher among the rural cohort only during summer. In wintertime, only the average concentration of the metabolite was the significant different $(p<0.001)$ between rural and urban populations [33]. The EDI of CIT was calculated as $0.043 \pm 0.099 \mu \mathrm{g} / \mathrm{kg}$ b.w./day in the summer and $0.304 \pm 0.776 \mu \mathrm{g} / \mathrm{kg}$ b.w./day in the wintertime. It was found that $10 \%$ (in summer) and $24 \%$ (in winter) of the enrolled participants surpassed the preliminary TDI established by EFSA $(0.2 \mu \mathrm{g} / \mathrm{kg}$ b.w./day). The worst-case scenario calculated among the participants corresponded to an EDI of $4.66 \mu \mathrm{g} / \mathrm{kg}$ b.w./day. As in a previously cited study [40], apart from for a positive trend observed between CIT biomarkers in urine and increased rice consumption, no significant correlations were observed [33].

According to a study performed in urines from volunteers in northern Nigeria, the positivity and levels of both CIT (incidence: 66\%; mean: $5.96 \mathrm{ng} / \mathrm{mL}$; max: $241 \mathrm{ng} / \mathrm{mL}$ ) and DH-CIT (incidence: 58\%; mean: $2.39 \mathrm{ng} / \mathrm{mL}$; max: $17 \mathrm{ng} / \mathrm{mL}$ ), were considerably higher in comparison with previous reported studies [42,48].

CIT analysis in urine from Tunisian population showed an average CIT concentration higher in colorectal cancer (CRC) patients than in controls, for mean levels either uncorrected or corrected for creatinine (ng/mg), $0.45 \pm 0.24$ vs $0.44 \pm 0.21$ and $0.95 \pm 1.43$ vs $0.53 \pm 0.48$, respectively [15]. In Wuhan, China, 60 urine samples from control volunteers $(n=30)$ and hepatocellular carcinoma patients (HCC) $(n=30)$ were evaluated. The concentrations were lower than the LOQ $(0.3 \mu \mathrm{g} / \mathrm{L})[49]$.

\subsection{Blood/Plasma}

Through the assessment of exposure biomarkers of CIT in the blood/plasma levels, information on internal circulation is made available, however the steady-state concentration has to be taken into account [43]. In plasma the median half-life for CIT is estimated as $9.4 \mathrm{~h}$. A provisional daily CIT intake was assessed based on both excretion of 'total CIT' in urine and reported urine biomarker information in different population groups. It was found that whereas the European surveyed population groups featured an exposure clearly below the TDI, in Bangladesh one biomonitoring study demonstrated that the TDI was surpassed for one population group [26].The levels found in plasma $(0.90 \mathrm{ng} / \mathrm{mL})$ were higher than in urine $(0.78 \mathrm{ng} / \mathrm{mL})[26]$.

Biomonitoring data of CIT in human blood, plasma or serum is still scarce, as shown in Table 1. In Germany, CIT was detected in all the plasma samples provided by four men and four women, with levels varying between from 0.10 to $0.25 \mathrm{ng} / \mathrm{mL}$. Despite its small-scale, this biomonitoring study supported a widespread exposure of Germany adults to CIT [22].

In Czech Republic, a high incidence of CIT (98\%) was also found in plasma samples from kidney tumor patients, with levels up to $182 \mathrm{ng} / \mathrm{L}$ (mean: $0.061 \pm 0.035 \mathrm{ng} / \mathrm{mL}$ ) [36]. In Tunisia, mean levels of CIT in plasma of both controls and patients with CRC was higher than the ones reported in previous studies. It was also noticeable that the levels between controls and patients with CRC did not differ [15]. The results from a survey in 60 plasma samples collected from HCC patients and control volunteers, in China (Wuhan), showed that only one sample from patients with HCC was contaminated, with a content of $0.63 \mu \mathrm{g} / \mathrm{L}$, a value very close to the LOQ, $0.44 \mu \mathrm{g} / \mathrm{L}$ [49].

Human exposure to CIT was also evaluated through plasma biomarker in Bangladesh [43]. The biomonitoring study analyzed CIT and DH-CIT in plasma from University students collected in two seasons: summer (June 2013; $n=64$ ) and winter (March 2014; $n=40$ ). CIT was found in higher frequency $(90 \%$ vs. $85 \%$ ) and maximum concentration levels $(2.70 \mathrm{vs.} 1.44 \mathrm{ng} / \mathrm{mL}$ ) in comparison with DH-CIT. It was also observed that the mean levels, of either CIT or DH-CIT were higher in winter $(0.47 \mathrm{vs} .0 .40 \mathrm{ng} / \mathrm{mL})$ than in summer $(0.25 \mathrm{vs} .0 .37 \mathrm{ng} / \mathrm{mL})$. Currently no information of the toxicokinetics of CIT is available and so it is not possible to estimate the dietary intake based on plasma biomarker levels $[14,33]$. It is also important to notice that according to a pilot study performed 
in a single volunteer, following the ingestion of a small dose of CIT, a cumulative excretion of roughly $36 \%$ (12\% corresponding to CIT and $24 \%$ to DH-CIT) was observed through analysis of $24 \mathrm{~h}$ urine. Such value has been applied before, among a Bangladeshi cohort, in the estimation of probable daily CIT intake values based on the urine levels found. In this way it was estimated that $24 \%$ of the enrolled population surpassed the TDI as proposed by EFSA (2012; $0.2 \mu \mathrm{g} / \mathrm{kg}$ bw/day) [14,33]. This is of concern, when taking into account that among the University student enrolled in the study cited before [43] it was also found a frequent co-occurrence to an additional mycotoxin OTA with acknowledged nephrotoxic effects [43].

\section{Analytical Methodologies}

Sampling, such as size and pre-treatment, extraction, clean-up as well as adequate and sensitive analytical methodologies for detection and quantification are key steps for the analysis of CIT and its metabolite in human biological fluids (urine and blood). Table 2 shows the sample size and its pre-treatment, extraction and clean-up procedures, detection and quantification methods, as well as the respective chromatographic conditions and the limits of detection (LODs) and quantification (LOQs) obtained for each methodology used so far for determination of these compounds in human biological fluids. 
Table 2. Analytical methods for determination of CIT and/or DH-CIT in human biological fluids.

\begin{tabular}{|c|c|c|c|c|c|c|c|c|c|}
\hline $\begin{array}{c}\begin{array}{c}\text { Biological } \\
\text { Fluids }\end{array} \\
\end{array}$ & $\begin{array}{c}\begin{array}{c}\text { Sample } \\
\text { Size }\end{array} \\
\text {. }\end{array}$ & $\begin{array}{c}\text { Sample } \\
\text { Pre-Treatment }\end{array}$ & Extraction & Clean-Up & $\begin{array}{l}\text { Detection and } \\
\text { Quantification }\end{array}$ & Chromatographic Conditions & $\begin{array}{c}\mathrm{LOD} \\
\mathrm{ng} / \mathrm{mL}\end{array}$ & $\begin{array}{c}\mathrm{LOQ} \\
\mathrm{ng} / \mathrm{mL}\end{array}$ & References \\
\hline Urine & $10 \mathrm{~mL}$ & $\begin{array}{l}\text { Centrifugation at } \\
4000 \times g ; 10 \text { min. }\end{array}$ & 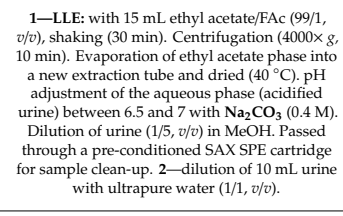 & 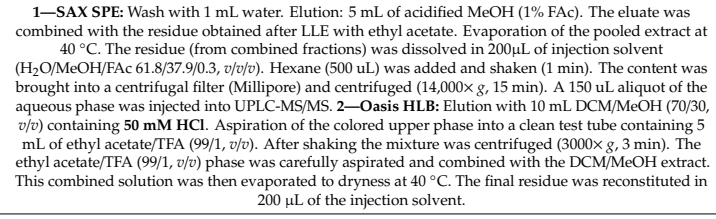 & $\begin{array}{l}\text { UPLC-MS/MS triple } \\
\text { quadrupole multiple } \\
\text { reaction monitorng } \\
\text { mode (MRM) Ionization: } \\
\text { ESI+ }\end{array}$ & 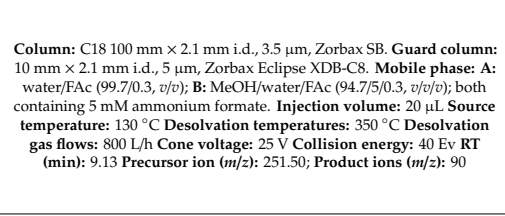 & СIT:288 & CIT:5.76 & [31] \\
\hline Urine & $20 \mathrm{~mL}$ & $\begin{array}{l}\text { Centrififugation at } \\
3940 \text { ref }\end{array}$ & $\begin{array}{l}5 \mathrm{~mL} \text { urine mixed with } 5 \mathrm{~mL} \text { of } 1 \mathrm{mM} \text { acetic } \\
\text { acid in water. }\end{array}$ & $\begin{array}{l}\text { C18: elution with } 3 \mathrm{~mL} \text { MeOH. Evaporation to dryness at } 40^{\circ} \mathrm{C} \text {. Dissolution of the residue in } 500 \mathrm{\mu L} \\
\text { MeOH. Filtration through Teflo syringe fitter }(0.45 \mathrm{\mu m}) \\
\text { IAC: elution with } 4 \mathrm{~mL} \text { of } \mathrm{MeOH} \text {. Evaporation to dryness }\left(40^{\circ} \mathrm{C}\right) \text {. } \\
\text { Dissolution of the residue in } 500 \mathrm{LL} \text { MeOH. }\end{array}$ & $\begin{array}{l}\text { HPLC-FD: } \\
\lambda \text { exc. } 330 \mathrm{~mm} ; \\
\lambda \text { em. } 500 \mathrm{~nm} \\
\\
\\
\text { LC-MS/MS Quadrupole } \\
\text { MS/MS equipped with an } \\
\text { ESI source }\end{array}$ & 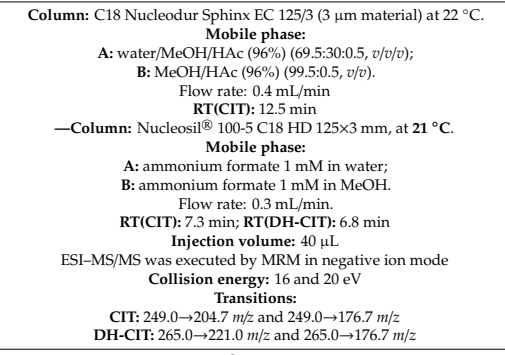 & $\begin{array}{l}\text { CTr: } 0.02 \\
\text { DH-CTI: } \\
\text { 0.05 }\end{array}$ & $\begin{array}{c}\text { CTT: } \\
\text { O.0.5 } \\
\text { DH-CT: } \\
0.10\end{array}$ & [22] \\
\hline Urine & $10 \mathrm{~mL}$ & $\begin{array}{c}\text { Centrifugation } \\
(16,800 \times 8,5 \text { min }) .\end{array}$ & Filtration through a RC syringe filter. & 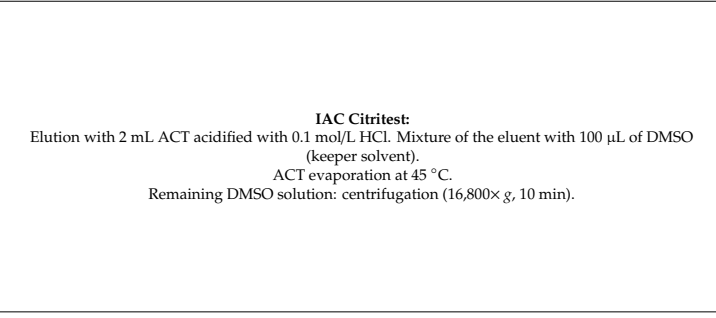 & UHPLC-MS & 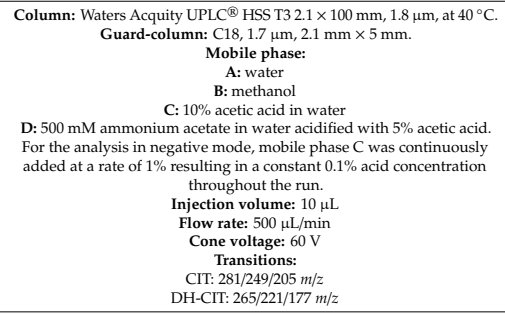 & $\begin{array}{l}\text { CIT: } 0.001 \\
\text { DH-CT: } \\
\text { O. } 010\end{array}$ & $\begin{array}{c}\text { CIT: } \\
\text { O.003 } \\
\text { DH-CIT: } \\
0.030\end{array}$ & [35] \\
\hline Urine & $20 \mathrm{~mL}$ & $\begin{array}{l}\text { Centrifugation at } \\
10,000 \text { rpm; } 5 \text { min }\end{array}$ & $\begin{array}{l}2 \mathrm{~mL} \text { : filtration with a syringe filter }(0.2 \mu \mathrm{mm}) \text {. } \\
\text { Fitter and shoot }\end{array}$ & - & $\begin{array}{l}\text { UHPIC-MS } \\
\text { Triple euadruple MRM } \\
\text { mode Positive ESI mode }\end{array}$ & 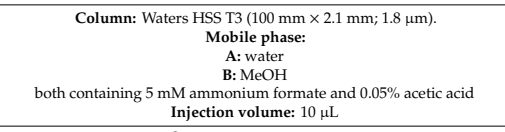 & $\begin{array}{l}\text { CIT: } 0.001 \\
\text { DH.CII: } \\
\text { O. } 010\end{array}$ & & {$[34,50]$} \\
\hline Urine & & $\begin{array}{l}\text { Centrifugation at } \\
14,000 \times g ; 10 \min \end{array}$ & 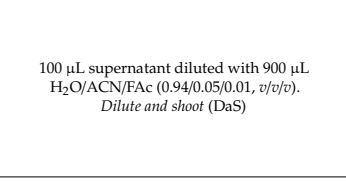 & - & $\begin{array}{l}\text { LC-MS/MS } \\
\text { QTRAP mass } \\
\text { Spectrometer } \\
\text { ESI negative mode } \\
\text { MRM }\end{array}$ & 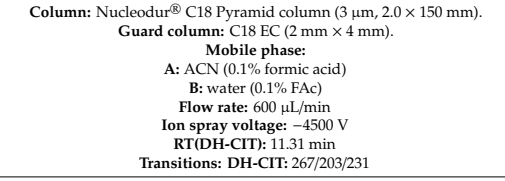 & $\underset{0.1}{\text { DH-CI: }}$ & $\underset{0.1}{\text { DH.CT: }}$ & [40] \\
\hline Urine & $5 \mathrm{~mL}$ & $\begin{array}{l}\text { Dilution with } 5 \\
\text { mL of } 1 \mathrm{mM} \text { acetic } \\
\text { acid in water, } \\
\text { mixed for } 15 \text { min. }\end{array}$ & - & 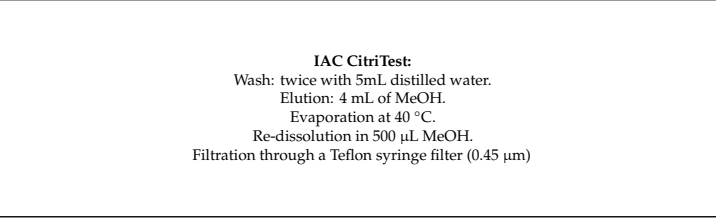 & $\begin{array}{l}\text { LC-MS/MS Quadrupole } \\
\text { MS/MS } \\
\text { ESI negative mode } \\
\text { MRM }\end{array}$ & 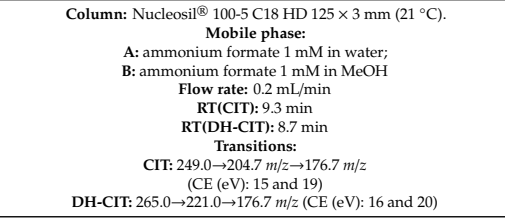 & $\begin{array}{l}\text { CIT:0.02 } \\
\text { DH-CIT: } \\
0.05\end{array}$ & $\begin{array}{l}\text { CTI:0.05 } \\
\text { DHHCCT: } \\
0.10\end{array}$ & {$[5,18]$} \\
\hline
\end{tabular}


Table 2. Cont.

\begin{tabular}{|c|c|c|c|c|c|c|c|c|c|}
\hline $\begin{array}{c}\text { Biological } \\
\text { Fluids } \\
\text { Fla }\end{array}$ & $\begin{array}{c}\text { Sample } \\
\text { Size }\end{array}$ & $\begin{array}{c}\text { Sample } \\
\text { Pre-Treatment }\end{array}$ & Extraction & Clean-Up & $\begin{array}{l}\text { Detection and } \\
\text { Quantification }\end{array}$ & Chromatographic Conditions & $\begin{array}{c}\mathrm{LOD} \\
\mathrm{ng} / \mathrm{mL}\end{array}$ & 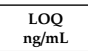 & References \\
\hline Urine & $500 \mathrm{\mu L}$ & $\begin{array}{l}\text { Centrifugation } \\
(5600 \times \text {, s min). } \\
\text { Incubation with } \\
500 \mu \mathrm{L} \text { PBS (pH } \\
7.4 \text { containing } \\
\beta-\text { glucuronidase } \\
\text { for } 16 \text { hat } 37^{\circ} \mathrm{C} \text {. }\end{array}$ & - & $\begin{array}{l}\text { Oasis PRiME HLB: } \\
\text { Wast: } 2 \times 500 \mathrm{HL} \mathrm{H}_{2} \mathrm{O} \\
\text { Elution: } 3 \times 2000 \mathrm{LL} \text { ACN. } \\
\text { Evaporation. } \\
\text { Re-dissolution: } 470 \text { HL mobile phase. }\end{array}$ & $\begin{array}{l}\text { UHPLC-MS/MS } \\
\text { ESI positive mode } \\
\text { MRM. }\end{array}$ & 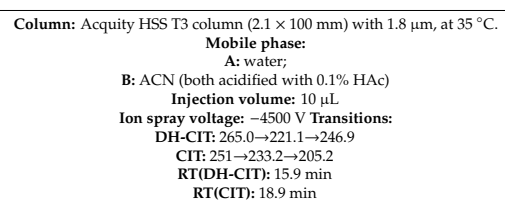 & $\begin{array}{l}\text { CIT: } 0.003 \\
\text { DH.CTI: } \\
0.003\end{array}$ & $\begin{array}{c}\text { CIT: } \\
\text { D.0. } \\
\text { DH-CT: } \\
0.01\end{array}$ & [42] \\
\hline Urine & $2 \mathrm{~mL}$ & 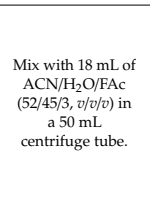 & 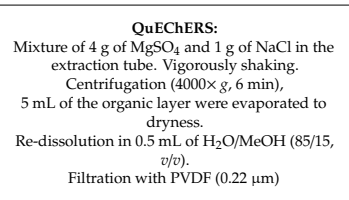 & - & $\begin{array}{l}\text { UPLC-MS/MS (TRS } \\
\text { mass spectrometer) } \\
\text { ESI negative mode. }\end{array}$ & 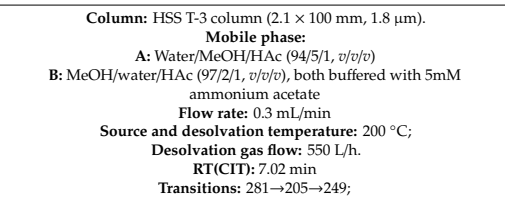 & спт: 0.5 & Стт: 1.0 & [38] \\
\hline Urine & $2 \mathrm{~mL}$ & 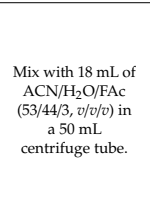 & 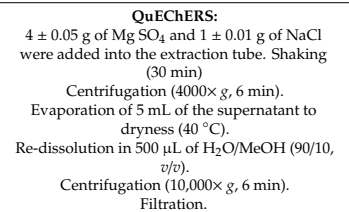 & - & UPLC-MS/MS & $\begin{array}{l}\text { Chromatographic conditions identical to those used by Martins et al. } \\
{[38] \text {. }}\end{array}$ & стт:0.14 & стт:0.20 & [15] \\
\hline Plasma & $1 \mathrm{~mL}$ & $\begin{array}{l}\text { Mix with } 1 \mathrm{~mL} \\
\text { ACN (1:1, v/v) to } \\
\text { precipitate } \\
\text { protein. }\end{array}$ & $\begin{array}{l}\text { Centrifugation }(9300 \mathrm{rpm}, 3 \mathrm{~min}) \text {. } \\
\text { Evaporation of } 1 \mathrm{~mL} \text { of the eupper alaer }\left(40^{\circ} \mathrm{C}\right) \\
\text { Reconstitution in } 300 \mathrm{\mu L} \mathrm{MeOH}\end{array}$ & - & $\begin{array}{l}\text { HPLC.FD: } \\
\text { exec: } 300 \mathrm{~mm} \\
\lambda \text { em : } 500 \mathrm{~nm} \\
\text { LC-MS/MS } \\
\end{array}$ & $\begin{array}{l}\text { Chromatographic conditions identical to those used for urine by } \\
\text { Blaszkewicz et al. [22]. }\end{array}$ & Сाт: 0.07 & $\begin{array}{l}\text { CIT: } \\
0.15\end{array}$ & [22] \\
\hline Plasma & $1 \mathrm{~mL}$ & 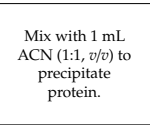 & 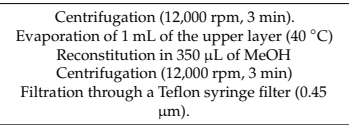 & - & LC-MS/MS & $\begin{array}{l}\text { Chromatographic conditions identical to those used for urine by Ali et } \\
\text { all }[5,18] \text {. }\end{array}$ & $\begin{array}{l}\text { CIт: } 0.07 \\
\text { DH.CT: } \\
0.15\end{array}$ & $\begin{array}{c}\text { CIT: } \\
0.15 \\
\text { DH-CIT: } \\
0.30\end{array}$ & [43] \\
\hline Plasma & $1 \mathrm{~mL}$ & 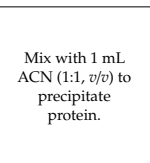 & 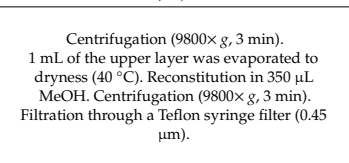 & - & LC-MS/MS & 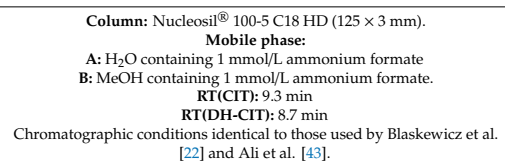 & $\begin{array}{c}\text { CIт: } 0.07 \\
\text { DH.СT: } \\
0.15\end{array}$ & $\begin{array}{c}\text { CIT: } \\
0.15 \\
\text { DH-CIT: } \\
0.30\end{array}$ & [36] \\
\hline Plasma & $1 \mathrm{~mL}$ & 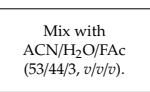 & $\begin{array}{l}\text { Extraction conditions identical to those used by } \\
\text { Martins et al. [37]. }\end{array}$ & Clean-up conditions identical to those used by Martins et al. [38]. & UPLC-MS/MS & $\begin{array}{c}\text { Chromatographic conditions identical to those used by Martins et al. } \\
\text { Transitions: } 281.0 \rightarrow 1.299 .0 \rightarrow 205.0 \mathrm{~m} / \mathrm{z} \\
\mathrm{RT}(\mathrm{TIT}): 8.5 \mathrm{~min}\end{array}$ & Стт: 0.04 & $\begin{array}{l}\text { CIT: } \\
0.09\end{array}$ & [15] \\
\hline Plasma & $200 \mathrm{\mu L}$ & $\begin{array}{l}\text { Add } 50 \mu \mathrm{L} \\
\beta \text {-glucuronidase. } \\
\text { Incubate } \\
\text { overnight at } 37 \pm \\
2^{\circ} \mathrm{C} \text { in a water } \\
\text { bath. }\end{array}$ & 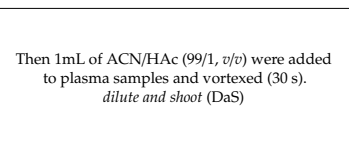 & 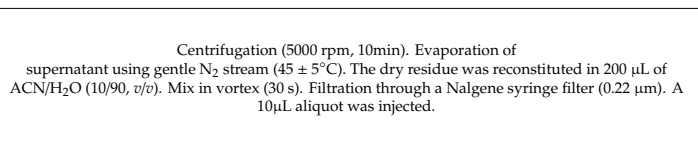 & $\begin{array}{l}\text { LC-MSMS } \\
\text { ESI positive mode }\end{array}$ & 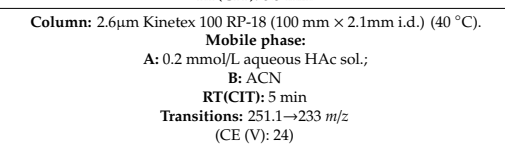 & Стт: 0.18 & $\begin{array}{l}\text { CIT: } \\
0.44\end{array}$ & [49] \\
\hline
\end{tabular}

ACN—acetonitrile; ACT—acetone; DCM—dichloromethane; DMSO—Dimethyl Sulfoxide; ES—extraction solvent; ESI—electrospray ionization; FAc—formic acid; HAc—glacial acetic

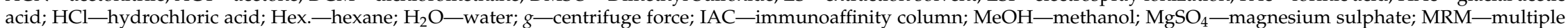
reaction monitoring; $\mathrm{N}_{2}$-nitrogen; $\mathrm{NaCl}$ - sodium chloride; $\mathrm{Na}_{2} \mathrm{CO}_{3}$ - sodium carbonate; $\mathrm{PVDF} —$ polyvinylidene fluoride; $\mathrm{RC}-$ regenerated cellulose membrane; $\mathrm{RT}-$ retention time; SPE—solid phase extraction; TFA—-trifluoracetic acid; TSF-Teflon syringe filter. 


\subsection{Urine}

\subsubsection{Sample Pre-Treatment}

The sample size varies between $500 \mu \mathrm{L}$ [42] and $20 \mathrm{~mL}$ [22,34,50]. Prior to the extraction process, several researchers used centrifugation to remove solid residues (Table 2). The centrifugal forces or spin speeds used are variable. Some of them used $4000 \times g$ for $10 \mathrm{~min}[31,34,50], 5600 \times \mathrm{g} / 3 \mathrm{~min}$, followed by incubation with $500 \mu \mathrm{L}$ PBS ( $\mathrm{pH} 7.4$ ) containing $\beta$-glucuronidase for $16 \mathrm{~h}$ at $37^{\circ} \mathrm{C}$ [42], $14,000 \times g$ during $10 \mathrm{~min}$ [40] or 16,800 $\times g$ for $5 \mathrm{~min}$ [34]. Others employed $3940 \mathrm{rfc}$ [22] or 10,000 rpm for $5 \mathrm{~min}$ [50]. A dilution with $5 \mathrm{~mL}$ of $1 \mathrm{mM}$ acetic acid in water followed by a mixture for $15 \mathrm{~min}$ was performed by some researchers $[5,18]$, while others opted by a mixture of $\mathrm{ACN} / \mathrm{H}_{2} \mathrm{O} / \mathrm{FAc}$ in different proportions [15].

\subsubsection{Extraction and Clean-Up Procedures}

A liquid-liquid extraction (LLE) with ethyl acetate acidified with formic acid, completed with SAX-SPE clean-up has proven to be a suitable pre-analytical set up [31] (Table 2). Furthermore, it is an alternative to the expensive and broadly employed immunoaffinity columns (IACs). When the obtained results with clean up by SAX and Oasis HLB SPE columns were compared, it was observed that the LODs were 3-9 times lower with SAX cartridges. Such difference could be ascribed to a better ability of the SAX columns to remove the matrix interferences, thus improving sample clean-up [31].

Blaszkewicz et al. [22], after centrifugation and urine acidification with an aqueous solution of acetic acid, used for SPE clean-up, C18 cartridges for HPLC-FD analysis and CitriTest ${ }^{\text {TM }}$ IAC columns before liquid chromatography coupled to mass spectrometry (LC-MS/MS) analysis. Various authors used these procedures to assess CIT and DH-CIT in human urine in different countries $[5,18,33,39,41]$.

Aliquots of $10 \mathrm{~mL}$ were centrifuged $(16,800 \times g, 5 \mathrm{~min})$ and passed through a RC syringe filter. After, an IAC cleanup with CitriTest ${ }^{\mathrm{TM}}$ columns was used. Elution was achieved with $2 \mathrm{~mL}$ acetone acidified with $\mathrm{HCl}(0.1 \mathrm{~mol} / \mathrm{L})$, followed by evaporation. A $10 \mu \mathrm{L}$ aliquot was injected in a ultra-high-performance liquid chromatography (UHPLC-MS/MS) instrument, with a gradient common to the direct method [35]. This analytical methodology presented high sensitivity, allowing LODs of 0.001 and $0.010 \mathrm{ng} / \mathrm{mL}$ for CIT and DH-CIT, respectively and LOQs of 0.003 and $0.030 \mathrm{ng} / \mathrm{mL}$, for CIT and its metabolite, respectively.

The extraction efficiency and the ability to reduce matrix interference in MS/MS chromatograms were compared between Oasis ${ }^{\circledR}$ HLB and PRiME HLB columns [42]. PRiME HLB columns were chosen since exhibited better extraction efficiency, $\mathrm{S} / \mathrm{N}$ ratios and a faster processing time. Furthermore, equilibration of the column allowed a faster clean-up. Different eluents were also evaluated namely $\mathrm{MeOH}(100 \%), \mathrm{ACN}(100 \%), \mathrm{MeOH} / \mathrm{ACN}(50 \% / 50 \%)$ and in some cases acidified with $1 \%$ HAc. Pure ACN resulted in higher extraction efficiency and elution was performed by using three times a volume of $200 \mu \mathrm{L}$ [42].

A QuEChERS-based procedure previously developed by Vidal et al. [51] was recently applied [38]. In a $50 \mathrm{~mL}$ centrifuge tube, $2 \mathrm{~mL}$ of urine were diluted in $18 \mathrm{~mL}$ of $\mathrm{ACN} / \mathrm{H}_{2} \mathrm{O} / \mathrm{FAc}(52 / 45 / 3, v / v / v)$. The mixture of $4 \mathrm{~g}$ of magnesium sulphate and $1 \mathrm{~g}$ of sodium chloride was followed by a $30 \mathrm{~min}$ vigorous agitation of the tube on a rotary shaker. The mixture was then centrifuged at $4000 \times g$ during $6 \mathrm{~min}$. Five $\mathrm{mL}$ of the resulting organic layer were evaporated to dryness under a gentle $\mathrm{N}_{2}$ stream at $40{ }^{\circ} \mathrm{C}$. The obtained residue was reconstituted in $0.5 \mathrm{~mL}$ of injection solvent $(\mathrm{H} 2 \mathrm{O} / \mathrm{MeOH}, 85 / 15$, $v / v)$, filtered through a PVDF membrane with $0.22 \mu \mathrm{m}$ pore size and analyzed by LC-MS/MS [38]. A similar procedure, with variations in solvent proportions, was also used in order to evaluate CIT levels in colorectal cancer patients in Tunisia [15]. Curiously, the last method showed better sensitivity (Table 2).

Heyndrickx et al. $[34,50]$ used one simplified methodology in which, after a 5 min centrifugation $(10,000 \mathrm{rpm}), 2 \mathrm{~mL}$ of urine was passed through a syringe filter $(0.2 \mu \mathrm{m})$. Gerding et al. [40,47], after centrifugation, simply diluted the supernatant by a factor of 10 in $\mathrm{H}_{2} \mathrm{O} / \mathrm{ACN} / \mathrm{FAc}$ before injection in the 
LC-MS/MS system. This rapid "dilute and shoot" (DaS) technique was also applied to evaluation of DH-CIT in urine samples from Swedish adolescents [46]. A simple DaS approach was also used to analyze urine samples $(200 \mu \mathrm{L})$ that were mixed with $730 \mu \mathrm{L}$ of $\mathrm{ACN} / \mathrm{H}_{2} \mathrm{O}(10 / 90, v / v)$. Afterward, the diluted sample was filtered with a syringe filter $\left(0.22 \mu \mathrm{m}\right.$; Nalgene $\left.{ }^{\mathrm{TM}}\right)$. Aliquots of $10 \mu \mathrm{L}$ were analyzed by LC-MS/MS [49].

\subsubsection{LC-FD and LC-MS-MS Quantification}

As shown in Table 2, detection and quantification by LC-MS/MS became more common. LC-FD may be an alternative given that, due to its planar structure, CIT has natural fluorescence, presenting highest fluorescence at $\mathrm{pH} 2.5$ by its nonionized molecule [24]. Chromatographic conditions are shown in the above mentioned table. Reverse phase is used, being the solid phase constituted by a nonpolar adsorbent, such as a C18 column and by a polar mobile phase. The column temperatures used are variable, usually between $21^{\circ} \mathrm{C}$ [22] and $40^{\circ} \mathrm{C}$ [35]. Regarding flow rates, when UPLC is used higher flow rates are employed, $800 \mathrm{~L} / \mathrm{h}[33]$ or $550 \mathrm{~L} / \mathrm{h}[15,38]$.

When LC-MS/MS or UPLC-MS/MS were used several mobile phase gradients were attempted. Several authors reported the used of water/formic acid $(99.7 / 0.3, v / v)$ and methanol/water/formic acid $(94.7 / 5 / 0.3, v / v / v)$, including both $5 \mathrm{mM}$ ammonium formate $[31,34,50]$. The mixture of $1 \mathrm{mM}$ ammonium formate in water and $1 \mathrm{mM}$ ammonium formate in $\mathrm{MeOH}$ was chosen by Blaszkewicz et al. and Ali et al. [5,18,22]. A quaternary system of water, methanol, 10\% acetic acid in water and $500 \mathrm{mM}$ ammonium acetate in water acidified with $5 \%$ acetic acid was also reported [35]. Acetonitrile and water, both acidified either with $0.1 \%$ formic acid $[40,47]$ or $0.1 \%$ acetic acid [42] were also described. A mixture of water/methanol/acetic acid $(94 / 5 / 1, v / v / v)$ and methanol/water/acetic acid $(97 / 2 / 1, v / v / v)$, both buffered with $5 \mathrm{mM}$ ammonium acetate [38] were applied. When LC-FD was employed the following mobile phases were used: water/methanol/acetic acid (96\%) (69.5:30:0.5, v/v/v) and methanol/acetic acid (96\%) $(99.5: 0.5, v / v)[22]$.

The great majority of authors use multiple reaction monitoring (MRM) with electron spray ionization (ESI) in negative mode (-) when UPLC $[15,35,38,42]$ or HPLC $[5,18,22,36,40,43]$ is used. More rarely, some researchers use MRM-ESI in positive mode $(+)[31,50]$.

Two distinctive MRM transitions are usually used to safeguard an accurate identification [40]. The precursor ion chosen for CIT vary between $249(\mathrm{~m} / z)[5,22]$ and $281 \mathrm{~m} / z$ [35,38]. The product ions, for the first precursor ion, were $204.7 \mathrm{~m} / \mathrm{z}$ and $176.7 \mathrm{~m} / \mathrm{z}[5,15,22]$ and for the second were 249 and $205 \mathrm{~m} / \mathrm{z}[35,38]$.

For DH-CIT, the precursor ion selected by different authors oscillated between $265 \mathrm{~m} / z[5,22,35,42]$ and $267 \mathrm{~m} / \mathrm{z}$ [40]. The products ions obtained for the first precursor ion were 221 and $176.7 \mathrm{~m} / \mathrm{z}[5,22,35]$. Šarkanj et al. [42] selected as product ions 221.1 and $246.9 \mathrm{~m} / \mathrm{z}$. For $267 \mathrm{~m} / \mathrm{z}$ precursor ion, the obtained products were 203 and $231 \mathrm{~m} / z$ [40].

According the chromatographic conditions, retention times for CIT oscillated between 7.3 [22] and $18.9 \mathrm{~min}$ [42] and for DH-CIT varied between 6.8 [22] and $15.9 \mathrm{~min}$ [42].

For CIT, the LOD values oscillated between 2.88 [31] and $0.001 \mathrm{ng} / \mathrm{mL}[34,35,50]$ and for DH-CIT among 0.1 [40] and $0.003 \mathrm{ng} / \mathrm{mL}$ [42]. The LOQ values for CIT were comprised between 5.76 [31] and $0.003 \mathrm{ng} / \mathrm{mL}$ [35] and for DH-CIT between 0.2 [15] and $0.01 \mathrm{ng} / \mathrm{mL}$ [42].

\subsection{Blood/Plasma}

\subsubsection{Sample Pre-Treatment, Extraction and Clean-Up}

For blood, a 15 min centrifugation at $3000 \mathrm{rpm}$ (roughly $1620 \times \mathrm{g}$ ), after addition of $2.7 \mathrm{~mL}$ $\mathrm{K}_{2}$ EDTA, allowed to obtain $4 \mathrm{~mL}$ of plasma. For plasma analysis, a protein precipitation step is required. Blaszkewicz et al. [22] mixed $1 \mathrm{~mL}$ of plasma with acetonitrile $(1: 1, v / v)$, followed by $3 \mathrm{~min}$ centrifugation at $9300 \mathrm{rcf}$. One $\mathrm{mL}$ of the upper layer was evaporated to dryness under a gentle 
nitrogen flow at $40{ }^{\circ} \mathrm{C}$. The residue was then dissolved in $300 \mu \mathrm{L}$ methanol before chromatographic analysis [22].

Similarly, Malir et al. [36] mixed $1 \mathrm{~mL}$ of plasma with $1 \mathrm{~mL}$ ACN $(1 / 1, v / v)$ before a $3 \mathrm{~min}$ centrifugation at $9800 \times \mathrm{g}$. One $\mathrm{mL}$ of the obtained upper layer was evaporated to dryness under a gentle $\mathrm{N}_{2}$ flow, at $40^{\circ} \mathrm{C}$. The residue was then dissolved in $350 \mu \mathrm{L}$ of MeOH, shaken in a vortex and centrifuged once more at $9800 \times g$ during $3 \mathrm{~min}$. The resulting extract was passed through a Teflon syringe filter $(0.45 \mu \mathrm{m})$ [36].

For plasma separation, Ali et al. [43] also used centrifugation, at $3000 \mathrm{rpm}(\cong 2500 \times g)$ during $15 \mathrm{~min}$. For protein precipitation, $1 \mathrm{~mL}$ of plasma sample was mixed with $1 \mathrm{~mL}$ ACN $(1: 1, v / v)$. Additional centrifugation at 12,000 rpm during $3 \mathrm{~min}$ followed. One $\mathrm{mL}$ of the resulting upper layer was evaporated to dryness under a gentle nitrogen flow at $40^{\circ} \mathrm{C}$. The residue was dissolved in $350 \mu \mathrm{L}$ of $\mathrm{MeOH}$, shaken in a vortex and centrifuged once more at 12,000 rpm during $3 \mathrm{~min}$. The resulting extract was finally passed through a Teflon syringe filter $(0.45 \mu \mathrm{m})$ [43].

Conversely to the results obtained for urine, the DaS procedure is not the most adequate for blood samples, given the possibility of forming blood clots and contaminate MS system. Therefore, in order to reduce as much as possible the sample preparation procedure, deproteinization with $\beta$-glucuronidase is possible [49].

Recently, as shown in Table 2, a QuEChERS methodology, similar to that used for urine samples, was also applied to plasma [15].

\subsubsection{LC-FD and LC-MS-MS Quantification}

For detection and quantification of CIT, LC-FD was used by Blaszkewicz et al. (2013) [22]. However, its presence at low concentrations in complex matrices, became LC-MS/MS the preferred method. Chromatographic conditions match those applied in urine samples and are specified in Table 2. For plasma, some methods exhibited identical LOD and LOQ values for CIT as for its metabolite [22,36,43], as shown in Table 2. One method showed higher sensitivity, being the LOD $0.04 \mathrm{ng} / \mathrm{mL}$ and the LOQ $0.09 \mathrm{ng} / \mathrm{mL}$ [15]. Conversely, the methodology proposed by Cao et al. [49] presented lower sensitivity, with LOD and LOQ values of 0.18 and $0.44 \mathrm{ng} / \mathrm{mL}$, respectively. It is acknowledged that the reliability of these methods is frequently compromised by matrix effects resulting in ion suppression or enhancement. According to a recent study of matrix effects in multi-residue analysis of mycotoxins in biological specimens a signal enhancement occurred in the case of CIT and suppression in the case of the metabolite DH-CIT [52]. It is therefore highly recommended the use of suitable, preferably isotope-labeled, internal standards for accurate quantification. In the last years, ${ }^{13} \mathrm{C}$-labeled reference standards for regulated mycotoxins become commercially available [53]. Stable isotope labeled internal standards, such as isotope labeled citrinin $\left({ }^{13} \mathrm{C}_{15} \mathrm{CIT}\right)$, were used especially in challenging biological matrices, as urine and plasma $[15,26,42,43]$. This use has the advantage to correct potential losses of mycotoxin throughout the analysis [15].

\section{Final Remarks}

Studies on the incidence of CIT and its major metabolite CH-CIT in biological fluids reveal a wide dissemination in different continents, such as Europe, Asia and Africa. Regarding urine, the data obtained so far reveal that the highest levels of CIT were found in Nigeria, $5.96 \pm 27.43 \mathrm{ng} / \mathrm{mL}$ [42], followed by Bangladesh, in winter, in a rural area, $0.66 \pm 0.91 \mathrm{ng} / \mathrm{mL}(1.16 \mathrm{ng} / \mathrm{mg}$ creatinine) [33] and in Tunisia, $0.45 \pm 0.24 \mathrm{ng} / \mathrm{mL}(0.95 \mathrm{ng} / \mathrm{mg}$ creatinine $)$ in patients with colorectal cancer [15]. Concerning DH-CIT, the highest levels were found in a rural area of Bangladesh, in the winter, $5.95 \pm 1.63 \mathrm{ng} / \mathrm{mL}$ (7.23 $\pm 12.2 \mathrm{ng} / \mathrm{mg}$ creatinine) [33], followed by $2.75 \pm 8.43 \mathrm{ng} / \mathrm{mL}$ (3.12 ng/mg crea) in the same area [40] and from Nigeria, with $2.39 \pm 3.56 \mathrm{ng} / \mathrm{mL}$ [42].

With respect to plasma matrix, DH-CIT was evaluated, so far, in only one study, in Bangladesh, in winter, reporting a mean level of $0.4 \pm 0.33 \mathrm{ng} / \mathrm{mL}$ [43]. CIT revealed higher plasma levels in Tunisia than in Bangladesh, $0.50 \pm 0.19 \mathrm{ng} / \mathrm{mL}$ vs. $0.47 \pm 0.5 \mathrm{ng} / \mathrm{mL}[15,43]$. 
Nowadays, LC/MS/MS-based methodologies are selected in order to reach the most required low detection limits for CIT and DH-CIT in biological fluids. However, matrix effects can present impairments for these methods. This can be avoided by efficient extraction and clean-up steps, usually consisting of centrifugation followed by solid phase extraction with C18 [22], SAX [31], polymeric [31,42] or IAC cartridges $[5,18,22,33,39,41]$ or through the use of QuEChERS-based procedures [38,51]. The DaS approach is a promising pre-analytical step in urine [47,49] or plasma [49], primarily in the presence of high levels of target analytes. However, it is required the absence of co-elution and interference of matrix components with ionization of the target analytes. Furthermore, the wide spectra of DaS compromises sensitivity [54]. Such effects can be compensated through the use of stable isotope-labeled standard of CIT. So, stable isotope dilution assays (SIDA) can circumvent part of these issues [8] thus facilitating biomonitoring studies [28].

Author Contributions: Conceptualization, C.L.; methodology, C.L and L.S.; investigation, C.L.; writing—original draft preparation, C.L and L.S.; writing-review and editing, C.L., L.S., S.D., A.P. (André Pereira) and A.P. (Angelina Pena); supervision, C.L.; project administration, C.L.; funding acquisition, Y.Y. All authors have read and agreed to the published version of the manuscript.

Funding: The work was supported by UIDB/50006/2020 with funding from FCT/MCTES through national funds.

Conflicts of Interest: The authors declare no conflict of interest.

\section{References}

1. Coppa, C.F.S.C.; Mousavi Khaneghah, A.; Alvito, P.; Assunção, R.; Martins, C.; Eş, I.; Gonçalves, B.L.; Valganon de Neeff, D.; Sant'Ana, A.S.; Corassin, C.H.; et al. The occurrence of mycotoxins in breast milk, fruit products and cereal-based infant formula: A review. Trends Food Sci. Technol. 2019, 92, 81-93. [CrossRef]

2. Ojuri, O.T.; Ezekiel, C.N.; Sulyok, M.; Ezeokoli, O.T.; Oyedele, O.A.; Ayeni, K.I.; Eskola, M.K.; Šarkanj, B.; Hajšlová, J.; Adeleke, R.A.; et al. Assessing the mycotoxicological risk from consumption of complementary foods by infants and young children in Nigeria. Food Chem. Toxicol. 2018, 121, 37-50. [CrossRef] [PubMed]

3. Selvaraj, J.N.; Wang, Y.; Zhou, L.; Zhao, Y.; Xing, F.; Dai, X.; Liu, Y. Recent mycotoxin survey data and advanced mycotoxin detection techniques reported from China: A review. Food Addit. Contam. Part A Chem. Anal. Control. Expo. Risk Assess. 2015, 32, 440-452. [CrossRef] [PubMed]

4. Scott, P.M. Other mycotoxins. In Mycotoxins in Food: Detection and Control; Magan, N., Olsen, M., Eds.; Woodhead Publishing Ltd., CRC Press LLC.: Cambridge, UK, 2004; pp. 1-471.

5. Ali, N.; Blaszkewicz, M.; Degen, G.H. Occurrence of the mycotoxin citrinin and its metabolite dihydrocitrinone in urines of German adults. Arch. Toxicol. 2015, 89, 573-578. [CrossRef]

6. Bennett, J.W.; Klich, M. Mycotoxins. Clin. Microbiol. Rev. 2003, 5, 497-516. [CrossRef]

7. Ostry, V.; Malir, F.; Ruprich, J. Producers and Important Dietary Sources of Ochratoxin A and Citrinin. Toxins 2013, 5, 1574-1586. [CrossRef]

8. Bergmann, D.; Hübner, F.; Wibbeling, B.; Daniliuc, C.; Cramer, B.; Humpf, H.U. Large-scale total synthesis of 13C3-labeled citrinin and its metabolite dihydrocitrinone. Mycotoxin Res. 2018, 34, 141-150. [CrossRef]

9. El Adlouni, C.; Tozlovanu, M.; Naman, F.; Faid, M.; Pfohl-Leszkowicz, A. Preliminary data on the presence of mycotoxins (ochratoxin A, citrinin and aflatoxin B1) in black table olives "Greek style" of Moroccan origin. Mol. Nutr. Food Res. 2006, 50, 507-512. [CrossRef] [PubMed]

10. Heperkan, D.; Meric, B.E.; Sismanoglu, G.; Dalkiliç, G.; Güler, F. Mycobiota, mycotoxigenic fungi, and citrinin production in black olives. In Advances in Experimental Medicine and Biology: Advances in Food Mycology; Hocking, A.D., Pitt, J.I., Samson, R.A., Thrane, U., Eds.; Springer Science+Business Media, Inc.: New York, NY, USA, 2006; Volume 571, p. 371.

11. Markov, K.; Pleadin, J.; Bevardi, M.; Vahčić, N.; Sokolić-Mihalak, D.; Frece, J. Natural occurrence of aflatoxin B1, ochratoxin A and citrinin in Croatian fermented meat products. Food Control 2013, 34, 312-317. [CrossRef]

12. Bailly, J.D.; Querin, A.; Le Bars-Bailly, S.; Benard, G.; Guerre, P. Citrinin production and stability in cheese. J. Food Prot. 2002, 65, 1317-1321. [CrossRef] [PubMed]

13. Martins, M.L.; Gimeno, A.; Martins, H.M.; Bernardo, F.; Gimeno, A.; Martins, H.M.; Co-occurrence, F.B.; Bernardo, F. Co-occurrence of patulin and citrinin in Portuguese apples with rotten spots. Food Addit. Contam. 2002, 19, 568-574. [CrossRef] [PubMed] 
14. EFSA. Risks for public and animal health related to the presence of citrinin in food and feed. EFSA J. 2012, 10,1-82. [CrossRef]

15. Ouhibi, S.; Vidal, A.; Martins, C.; Gali, R.; Hedhili, A.; De Saeger, S.; De Boevre, M. LC-MS/MS methodology for simultaneous determination of patulin and citrinin in urine and plasma applied to a pilot study in colorectal cancer patients. Food Chem. Toxicol. 2020, 136, 110994. [CrossRef] [PubMed]

16. Adam, M.A.A.; Tabana, Y.M.; Musa, K.B.; Sandai, D.A. Effects of different mycotoxins on humans, cell genome and their involvement in cancer. Oncol. Rep. 2017, 37, 1321-1336. [CrossRef] [PubMed]

17. Sweeney, M.J.; Dobson, A.D.W. Mycotoxin production by Aspergillus, Fusarium and Penicillium species. Int. J. Food Microbiol. 1998, 43, 141-158. [CrossRef]

18. Ali, N.; Blaszkewicz, M.; Mohanto, N.C.; Rahman, M.; Alim, A.; Hossain, K.; Degen, G.H. First results on citrinin biomarkers in urines from rural and urban cohorts in Bangladesh. Mycotoxin Res. 2015, 31, 9-16. [CrossRef]

19. Peraica, M.; Domijan, A.-M.; Miletić-Medved, M.; Fuchs, R. The involvement of mycotoxins in the development of endemic nephropathy. Wien. Klin. Wochenschr. 2008, 120, 402. [CrossRef] [PubMed]

20. Pfohl-Leszkowicz, A. Ochratoxin A and Aristolochic Acid Involvement in Nephropathies and Associated Urothelial Tract Tumours. Arch. Ind. Hyg. Toxicol. 2009, 60, 465-483. [CrossRef] [PubMed]

21. Faisal, Z.; Vörös, V.; Lemli, B.; Derdák, D.; Kunsági-Máté, S.; Bálint, M.; Hetényi, C.; Csepregi, R.; Kőszegi, T.; Bergmann, D.; et al. Interaction of the mycotoxin metabolite dihydrocitrinone with serum albumin. Mycotoxin Res. 2019, 35, 129-139. [CrossRef]

22. Blaszkewicz, M.; Muñoz, K.; Degen, G.H. Methods for analysis of citrinin in human blood and urine. Arch. Toxicol. 2013, 87, 1087-1094. [CrossRef] [PubMed]

23. Föllmann, W.; Behm, C.; Degen, G.H. Toxicity of the mycotoxin citrinin and its metabolite dihydrocitrinone and of mixtures of citrinin and ochratoxin A in vitro. Arch. Toxicol. 2014, 88, 1097-1107. [CrossRef]

24. Doughari, J. The Occurrence, Properties and Significance of Citrinin Mycotoxin. J. Plant Pathol. Microbiol. 2015, 6, 1-6. [CrossRef]

25. De Oliveira Filho, J.W.G.; Islam, M.T.; Ali, E.S.; Uddin, S.J.; de Oliveira Santos, J.V.; de Alencar, M.V.O.B.; Júnior, A.L.G.; Paz, M.F.C.J.; de Brito, M.d.R.M.; e Sousa, J.M.d.C.; et al. A comprehensive review on biological properties of citrinin. Food Chem. Toxicol. 2017, 110, 130-141. [CrossRef]

26. Degen, G.H.; Ali, N.; Gundert-Remy, U. Preliminary data on citrinin kinetics in humans and their use to estimate citrinin exposure based on biomarkers. Toxicol. Lett. 2018, 282, 43-48. [CrossRef]

27. Degen, G.H.; Partosch, F.; Muñoz, K.; Gundert-Remy, U. Daily uptake of mycotoxins_TDI might not be protective for nursed infants. Toxicol. Lett. 2017, 277, 69-75. [CrossRef] [PubMed]

28. Ali, N.; Degen, G.H. Citrinin biomarkers: A review of recent data and application to human exposure assessment. Arch. Toxicol. 2019, 93, 3057-3066. [CrossRef] [PubMed]

29. Duarte, S.C.; Pena, A.; Lino, C.M. Human ochratoxin A biomarkers-From exposure to effect. Crit. Rev. Toxicol. 2011, 41, 187-212. [CrossRef] [PubMed]

30. Marín, S.; Cano-Sancho, G.; Sanchis, V.; Ramos, A.J. The role of mycotoxins in the human exposome: Application of mycotoxin biomarkers in exposome-health studies. Food Chem. Toxicol. 2018, 121, 504-518. [CrossRef] [PubMed]

31. Ediage, E.N.; Diana Di Mavungu, J.; Song, S.; Wu, A.; Van Peteghem, C.; De Saeger, S. A direct assessment of mycotoxin biomarkers in human urine samples by liquid chromatography tandem mass spectrometry. Anal. Chim. Acta 2012, 741, 58-69. [CrossRef]

32. Vidal, A.; Mengelers, M.; Yang, S.; De Saeger, S.; De Boevre, M. Mycotoxin Biomarkers of Exposure: A Comprehensive Review. Compr. Rev. Food Sci. Food Saf. 2018, 17, 1127-1155. [CrossRef]

33. Ali, N.; Blaszkewicz, M.; Alim, A.; Hossain, K.; Degen, G.H. Urinary biomarkers of ochratoxin A and citrinin exposure in two Bangladeshi cohorts: Follow-up study on regional and seasonal influences. Arch. Toxicol. 2016, 90, 2683-2697. [CrossRef]

34. Heyndrickx, E.; Sioen, I.; Huybrechts, B.; Callebaut, A.; De Henauw, S.; De Saeger, S. Human biomonitoring of multiple mycotoxins in the Belgian population: Results of the BIOMYCO study. Environ. Int. 2015, 84, 82-89. [CrossRef] [PubMed] 
35. Huybrechts, B.; Martins, J.C.; Debongnie, P.; Uhlig, S.; Callebaut, A. Fast and sensitive LC-MS/MS method measuring human mycotoxin exposure using biomarkers in urine. Arch. Toxicol. 2015, 89, 1993-2005. [CrossRef] [PubMed]

36. Malir, F.; Louda, M.; Ostry, V.; Toman, J.; Ali, N.; Grosse, Y.; Malirova, E.; Pacovsky, J.; Pickova, D.; Brodak, M.; et al. Analyses of biomarkers of exposure to nephrotoxic mycotoxins in a cohort of patients with renal tumours. Mycotoxin Res. 2019, 35, 391-403. [CrossRef] [PubMed]

37. Viegas, S.; Assunção, R.; Nunes, C.; Osteresch, B.; Twarużek, M.; Kosicki, R.; Grajewski, J.; Martins, C.; Alvito, P.; Almeida, A.; et al. Exposure assessment to mycotoxins in a Portuguese fresh bread dough company by using a multi-biomarker approach. Toxins 2018, 10, 342. [CrossRef] [PubMed]

38. Martins, C.; Vidal, A.; De Boevre, M.; De Saeger, S.; Nunes, C.; Torres, D.; Goios, A.; Lopes, C.; Assunção, R.; Alvito, P. Exposure assessment of Portuguese population to multiple mycotoxins: The human biomonitoring approach. Int. J. Hyg. Environ. Health 2019, 222, 913-925. [CrossRef] [PubMed]

39. Föllmann, W.; Ali, N.; Blaszkewicz, M.; Degen, G.H. Biomonitoring of Mycotoxins in Urine: Pilot Study in Mill Workers. J. Toxicol. Environ. Heal. Part A Curr. Issues 2016, 79, 1015-1025. [CrossRef] [PubMed]

40. Gerding, J.; Ali, N.; Schwartzbord, J.; Cramer, B.; Brown, D.L.; Degen, G.H.; Humpf, H.U. A comparative study of the human urinary mycotoxin excretion patterns in Bangladesh, Germany, and Haiti using a rapid and sensitive LC-MS/MS approach. Mycotoxin Res. 2015, 31, 127-136. [CrossRef] [PubMed]

41. Ali, N.; Blaszkewicz, M.; Manirujjaman, M.; Degen, G.H. Biomonitoring of concurrent exposure to ochratoxin A and citrinin in pregnant women in Bangladesh. Mycotoxin Res. 2016, 32, 163-172. [CrossRef]

42. Šarkanj, B.; Ezekiel, C.N.; Turner, P.C.; Abia, W.A.; Rychlik, M.; Krska, R.; Sulyok, M.; Warth, B. Ultra-sensitive, stable isotope assisted quantification of multiple urinary mycotoxin exposure biomarkers. Anal. Chim. Acta 2018, 1019, 84-92. [CrossRef]

43. Ali, N.; Hossain, K.; Degen, G.H. Blood plasma biomarkers of citrinin and ochratoxin A exposure in young adults in Bangladesh. Mycotoxin Res. 2018, 34, 59-67. [CrossRef] [PubMed]

44. Dunn, B.B.; Stack, M.E.; Park, D.L.; Joshi, A.; Friedman, L.; King, R.L. Isolation and identification of dihydrocitrinone, a urinary metabolite of citrinin in rats. J. Toxicol. Environ. Health 1983, 12, $283-289$. [CrossRef] [PubMed]

45. Viegas, S.; Assunção, R.; Martins, C.; Nunes, C.; Osteresch, B.; Twarużek, M.; Kosicki, R.; Grajewski, J.; Ribeiro, E.; Viegas, C. Occupational exposure to mycotoxins in swine production: Environmental and biological monitoring approaches. Toxins 2019, 11, 78. [CrossRef] [PubMed]

46. Lemming, E.W.; Montano Montes, A.; Schmidt, J.; Cramer, B.; Humpf, H.U.; Moraeus, L.; Olsen, M. Mycotoxins in blood and urine of Swedish adolescents-Possible associations to food intake and other background characteristics. Mycotoxin Res. 2020, 36, 193-206. [CrossRef] [PubMed]

47. Gerding, J.; Cramer, B.; Humpf, H.U. Determination of mycotoxin exposure in Germany using an LC-MS/MS multibiomarker approach. Mol. Nutr. Food Res. 2014, 58, 2358-2368. [CrossRef]

48. Ezekiel, C.N.; Warth, B.; Ogara, I.M.; Abia, W.A.; Ezekiel, V.C.; Atehnkeng, J.; Sulyok, M.; Turner, P.C.; Tayo, G.O.; Krska, R.; et al. Mycotoxin exposure in rural residents in northern Nigeria: A pilot study using multi-urinary biomarkers. Environ. Int. 2014, 66, 138-145. [CrossRef]

49. Cao, X.; Li, X.; Li, J.; Niu, Y.; Shi, L.; Fang, Z.; Zhang, T.; Ding, H. Quantitative determination of carcinogenic mycotoxins in human and animal biological matrices and animal-derived foods using multi-mycotoxin and analyte-specific high performance liquid chromatography-tandem mass spectrometric methods. J. Chromatogr. B Anal. Technol. Biomed. Life Sci. 2018, 1073, 191-200. [CrossRef]

50. Heyndrickx, E.; Sioen, I.; Bellemans, M.; De Maeyer, M.; Callebaut, A.; De Henauw, S.; De Saeger, S. Assessment of mycotoxin exposure in the Belgian population using biomarkers: Aim, design and methods of the BIOMYCO study. Food Addit. Contam. Part A Chem. Anal. Control. Expo. Risk Assess. 2014, 31, 924-931. [CrossRef]

51. Vidal, A.; Claeys, L.; Mengelers, M.; Vanhoorne, V.; Vervaet, C.; Huybrechts, B.; De Saeger, S.; De Boevre, M. Humans significantly metabolize and excrete the mycotoxin deoxynivalenol and its modified form deoxynivalenol-3-glucoside within 24 hours. Sci. Rep. 2018, 8, 1-11. [CrossRef]

52. Osteresch, B.; Viegas, S.; Cramer, B.; Humpf, H.U. Multi-mycotoxin analysis using dried blood spots and dried serum spots. Anal. Bioanal. Chem. 2017, 409, 3369-3382. [CrossRef] 
53. Warth, B.; Braun, D.; Ezekiel, C.N.; Turner, P.C.; Degen, G.H.; Marko, D. Biomonitoring of Mycotoxins in Human Breast Milk: Current State and Future Perspectives. Chem. Res. Toxicol. 2016, 29, 1087-1097. [CrossRef] [PubMed]

54. Song, S.; Ediage, E.N.; Wu, A.; De Saeger, S. Development and application of salting-out assisted liquid/liquid extraction for multi-mycotoxin biomarkers analysis in pig urine with high performance liquid chromatography/tandem mass spectrometry. J. Chromatogr. A 2013, 1292, 111-120. [CrossRef] [PubMed]

(C) 2020 by the authors. Licensee MDPI, Basel, Switzerland. This article is an open access article distributed under the terms and conditions of the Creative Commons Attribution (CC BY) license (http://creativecommons.org/licenses/by/4.0/). 